\title{
Esophageal varices and early esophageal cancer: can we perform endoscopic mucosal resection (EMR)?
}

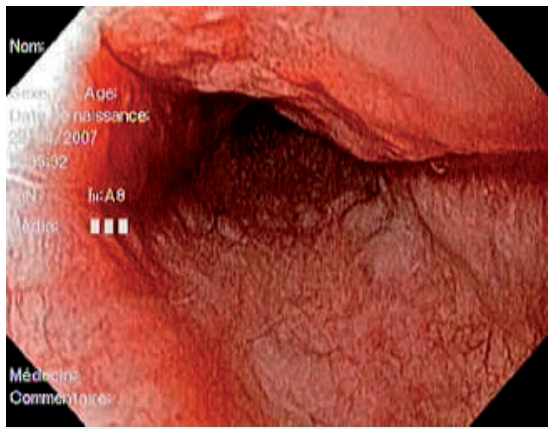

Fig. 1 A superficial carcinoma type 0-llb, $5 \mathrm{~cm}$ in length, stretched over three-quarters of the esophageal circumference (patient \# 4).

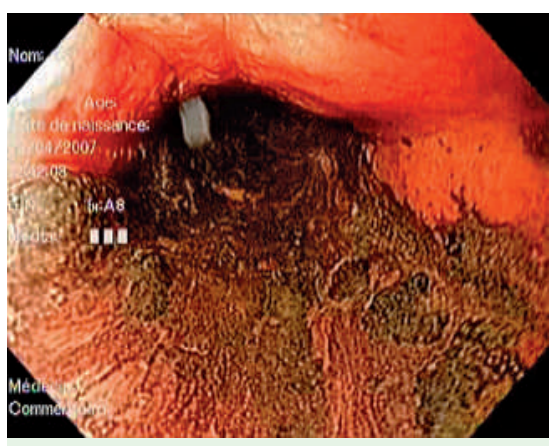

Fig. 2 Endoscopic view of the upper part of the lesion after Lugol $2 \%$ chromoscopy. Note the unstained pink/orange neoplastic area (patient \#4).

We present four patients (\#1-4) with esophageal varices due to alcoholic liver cirrhosis diagnosed between June 2006 and July 2007 with early esophageal squamous cell carcinoma (SCC). Cancers were treated by endoscopic mucosal resection (EMR).

Patients were male smokers with a mean age of 64 years. Cirrhosis classifications were Child-Pugh A or B (6 or 7 points), and variceal grades were 1 or 2 [1]. Two patients had a history of esophageal variceal ligation (EVL) for primary (\# 4) and secondary (\# 2) variceal bleeding prophylaxis, 3 and 5 years before current cancer diagnosis, respectively.

Cancers were found during cirrhosis initial evaluation (\#1 and \# 3) or esophageal varices surveillance (\# 2 and \# 4). Lesions were superficial type 0 -II [2], were $2-5 \mathrm{~cm}$ in length, occupied a third to three-quarters of the esophageal circum-

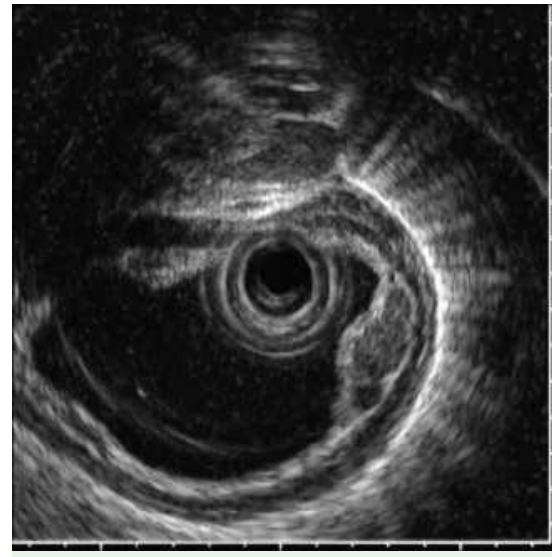

Fig. 3 Esophageal varices in the submucosa beneath the lesion as demonstrated by endoscopic ultrasound examination. Lesion staged uT1mN0 (patient \#4).

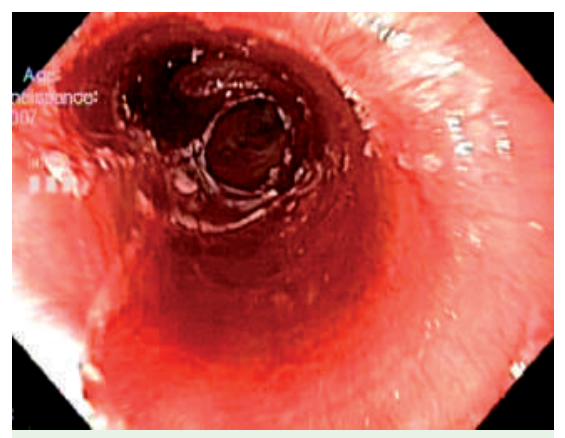

Fig. 4 Endoscopic aspect immediately at the end of the endoscopic mucosal resection session (patient \# 4).

ference, and were staged uT1N0 by endoscopic ultrasound (EUS). EUS also noticed esophageal varices passing in the submucosa beneath the lesions ( $\bullet$ Fig. 1-3).

Before EMR, variceal eradication by EVL (1-3 sessions) was carried out in all patients except one (\#1), in whom ligation was preformed at the same time as EMR. All lesions were resected piece-meal using the cap-assisted technique during a single EMR session ( $\bullet$ Fig.4). There were no complications apart from two immediate bleedings, which were stopped by metallic clips (\# 2) and hot forceps (\# 4). Coagulation factor V level was $58 \%$ to $92 \%$, and platelet count was $88000 /$ $\mathrm{cmm}$ to $158000 / \mathrm{cmm}$.

One patient (\#2) died of mesenteric infarction 1 week after EMR, whereas the other three patients were disease free after a median follow-up of 7 months (range 5-17).

Three similar reports were found in the literature [3 - 5], in all cases sclerotherapy or EVL were done before EMR. Here for one patient EVL was done at the same time as EMR.

Overall EMR is feasible for early esophageal SCC in liver cirrhosis patients with esophageal varices.

Endoscopy_UCTN_Code_CPL_1AH_2AZ

M. Ciocîrlan, M. Chemali, M.-G. Lapalus, C. Lefort, J. C. Souquet, B. Napoléon,

\section{T. Ponchon}

Hépatogastroentérologie, Hôpital

Édouard Herriot, Lyon, France

\section{References}

1 Child CG, Turcotte JG. Surgery and portal hypertension. In: Child CG (ed). The liver and portal hypertension.Philadelphia Saunders; 1964: 1 - 85

2 Paris Workshop Participants. The Paris endoscopic classification of superficial neoplastic lesions: esophagus, stomach and colon. Gastrointest Endosc 2003; 58: S3-S43

3 Inoue $H$, Endo M, Takeshita $K$ et al. Endoscopic resection of carcinoma in situ of the esophagus accompanied by esophageal varices. Surg Endosc 1991; 5: 182 - 184

4 Funakoshi K, Akiyama N, Kozakai I et al. Successful endoscopic therapy of superficial esophageal cancer on varices in a patient with alcoholic liver cirrhosis. Dig Endosc 2001; 13: 212-215

5 Endlicher E, Gelbmann C, Schlottmann Ket al. Endoscopic mucosal resection for early esophageal cancer with esophageal varices (in German). Z Gastroenterol 2004; 42: 609-613

\section{Bibliography}

DOI $10.1055 / \mathrm{s}-2007-995571$

Endoscopy 2008; 40: E91

(c) Georg Thieme Verlag KG Stuttgart · New York . ISSN 0013-726X

\section{Corresponding author}

\section{Ciocîrlan, MD}

Hépatogastroentérologie

Hôpital Édouard Herriot

5 Place d'Arsonval

69437 Lyon

France

Fax: +33-4-72110147

ciocirlanm@yahoo.com 